\title{
Estimating late-winter heat flow to the atmosphere from the lake-dominated Alaskan North Slope
}

\author{
Martin O. Jeffries, ${ }^{1}$ Tingjun Zhang, ${ }^{2}$ Karoline. Frey, ${ }^{3}$ Nick Kozlenko ${ }^{1}$ \\ ${ }^{\mathrm{I} G e o p h y s i c a l}$ Institute, University of Alaska Fairbanks, Fairbanks, Alaska 99775-7320, U.S.A. \\ ${ }^{2}$ Division of Cryospheric and Polar Processes, Cooperative Instilute for Research in Environmental Sciences (CIRES), \\ Campus Box 449, Lnizersity of Colorado, Boulder, Colorado 80309, U.S.A. \\ ${ }^{3}$ Institul für Meteorologie und Klimaforschung, Universität Karlsruhe, D-76128 Karlsruhe, Germany
}

\begin{abstract}
The conductive heat flux through the snow cover $\left(F_{\mathrm{a}}\right)$ is used as a proxy to examine the hypothesis that there is a significant heat flow from the Alaskan North Slope to the atmosphere because of the large number of lakes in the region. $F_{\mathrm{a}}$ is estimated from measurcments of snow depth, temperature and density on tundra, grounded ice and floating ice in mid-April 1997 at six lakes ncar Barrow, northwestern Alaska. The mean $F_{\text {a }}$ values from tundra, grounded ice and floating icc are $1.5,5.4$ and $18.6 \mathrm{~W} \mathrm{~m}{ }^{2}$, respectively. $\Lambda$ numerical model of the coupled snow/ice/water/soil system is used to simulate $F_{\text {a }}$ and there is good agreement between the simulated and measured fluxes. The flux from the tundra is low because the soils have a relatively low thermal conductivity and the active layer cools significantly after freczing completcly the previous autumn. The flux from the floating ice is high because the ice has a relatively high thermal conductivity, and a body of relatively warm water remains below the growing ice at the end of winter. The flux from the grounded ice is intermediate between that from the tundra and that from the floating ice, and dcpends on the timing of the contact between the growing ice and the lake sediments, and whether or not those sediments freeze completcly. Lsing the estimated $F_{\text {a }}$ values combined with the areal fractions of tundra, grounded icc and floating ice derived from synthetic aperture radar images, area-wcighted $F_{\mathrm{a}}$ values are calculated for six areas. $F_{\mathrm{a}}$ values for the ice vary between 9.8 and $13.8 \mathrm{~W} \mathrm{~m}^{-2}$, and those from the ice plus tundra vary between 3.9 and $5.3 \mathrm{~W} \mathrm{~m}^{-2}$. The $F_{\mathrm{a}}$ values are similar to those observed in the sea-ice-covered regions of the south and north polar oceans in winter. The North Slope of Alaska may thus make a significant contribution to the regional energy budget in winter.
\end{abstract}

\section{INTRODUCTION}

In the Arctic Ocean, the net heat loss from a relatively small area of open water and thin ice is $1-2$ orders of magnitude greater than from the snow-covered multiyear ice that covers most of the Arctic basin (Maykut, 1978, 1982; I.edley, 1988). The large heat flux from leads and thin ice can dominate regional heat fluxes and affect even the global climate (Smith and others, 1990). Quantifying the spatial and temporal variability of the heat fluxes from ocean to atmosphere in the Arctic seas is a key component of understanding the surface cnergy budget, the role of the Arctic Occan in the regional and global climate system and the sensitivity of the sea-icc cover to climate changc (Moritz and Pcrovich, 1996).

The land surrounding the Arctic Ocean must also be taken into account in studies of the regional and global climate system. Numerical simulations of the global climate-system responsc to increased atmospheric $\mathrm{CO}_{2}$ concentration indicate that the strongest warming will occur over northern land areas (c.g. Manabe and Stouffer, 1994). Analysis of Arctic air-temperature records indicates that the warming of northern land areas, including Alaska, may already be under way (Chapman and Walsh, 1993). Understanding the climatic role of the lands surrounding the Arctic Ocean and their sensitivity to climate change also requires a knowledge of the surface energy budget, including the spatial and temporal variability of the energy sources.

One region of interest in this regard is the North Slope of Alaska, wherc there are thousands of shallow, thaw lakes that cover as much as $40 \%$ of the tundra in some areas (Sellmann and others, 1975). Typically, the lakes are completely ice-covered by late September and the ice has melted completely from even the deepest lakes by mid- to late July (Brewer, 1958; Scllmann and others, 1975). Many lakes are, in their entirety or in part, shallower than the maximum annual ice thickness; conscquently, some icc freczes completely to the bottom. Nevertheless, large areas of water are decper than the maximum ice thickness and the ice remains afloat throughout the winter, as the late-winter synthetic aperture radar (SAR) image shows (Fig. 1).

Hcat-flux plate measurcments and calculations have shown that the heat flow from the tundra is typically $\leq 5 \mathrm{Wm}^{2}$ at the end of winter (Hinzman and others, 1991a, b; Sturm and Holmgren, 1994). At the same time, there should be a greater heat flow from the lakes, particularly if the ice that remains afloat is growing. Furthermore, since the total area of floating ice at the end of winter is large, as the SAR image shows (Fig. 1), the area-weighted heat flow should also be large. This papcr describes a field, remotc-scnsing and numerical modelling investigation of 


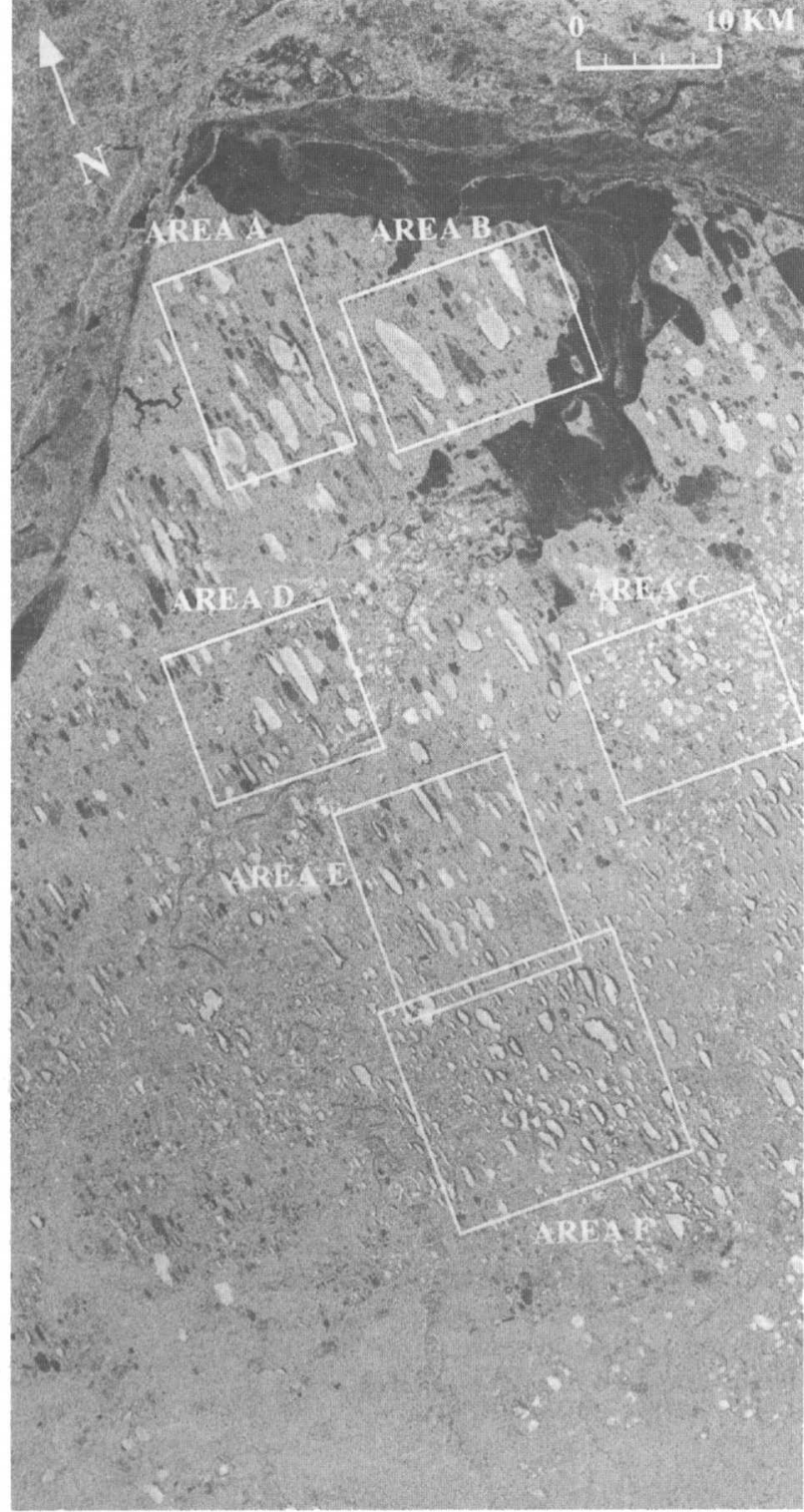

Fig. 1. Geocoded ERS-2 SAR image of the region up to $200 \mathrm{~km}$ south of Barrow, northwestern Alaska, on 19 April 1997. The boxes identify the areas for which area-weighted conductive heat fluxes have been calculated. The image is made up of two original $S A R$ scenes, which are $\mathrm{C}$ European Space Agency ( ESA).

late-winter encrgy sources on the Alaskan North Slope. We examinc the hypothesis that there is a significant heat flow from the Alaskan North Slope to the atmosphere because of the large number of lakes. Our proxy for the heat flow is the conductive heat flux through the snow cover.

\section{STUDY AREA AND METHODS}

The field investigation occurred during the period 12-18 April 1997 near Barrow, northwestern Alaska (Fig. 1), at six lakes (Fig. 2; Table 1) that had been studied previously by Jeffries and others (1994). They were selected for this investigation because (a) they were known to offer a good sample of different charactcristics (water depth/ice thickness, presence/absence of floating ice and grounded ice), and (b) they were relatively easy to locatc in a rather featureless late-winter landscape.

At Imikpuk lake (Fig. 2), an I-shaped observation transect was established. It comprised a $220 \mathrm{~m}$ long section from the tundra across the grounded ice margin onto the floating ice, and, oriented perpendicular to that, a $160 \mathrm{~m}$ long section located entircly on floating ice. At the other five lakes, a single, straight, $160 \mathrm{~m}$ long transect was laid out, beginning on the cundra and ending on the lake ice. At Emaiksoun and Ikroavik lakcs, as at Imikpuk lake, the transects included tundra, grounded ice and floating ice (Table 1). At Vishio, Hiro and Martin lakes (these are unofficial names corresponding to sites 6,7 and 11 , respectively, that were investigated previously by Jeffries and others, 1994) the lake portion of the transects included only grounded ice (Table 1). The floating and grounded ice were distinguished from one another on the basis of a combination of differences in appearance of the ice (nloating ice was black; grounded ice was grey and often had vegetation piercing the surface) followed by drilling with an electric-powered, $50 \mathrm{~mm}$ ice auger to confirm the identification of each ice type. In addition, a total of 31 floating ice-thickness measurements was obtaincd along transects at Imikpuk $(n=20)$ and Ikroavik $(n=11)$ lakes to obtain a mean ice-thickness value $(1.53 \mathrm{~m})$ that was used subsequently for running the numerical model in "data-assimilation" mode.

At cach lake, the snow depth was measured at $2 \mathrm{~m}$ intervals along the transects. A thin probe, marked in mm, was pushed down to the base of the snow, and the depth was read from the side of the probe to an accuracy of $5 \mathrm{~mm}$. A digital thermometer (accuracy $0.1^{\circ} \mathrm{C}$ ) was used to measure the temperature of a thermistor at the tip of the probe after it had equilibrated. The number of snow-depth and snow-base temperature measurements at each lake is summarized in Table 2. The same probe, but shielded from direct solar radiation, was used to measure the snow-surface (skin) temperature at the first $\left(T_{1}\right)$ and last point $\left(T_{2}\right)$ on cach transect. The time elapsed between the first and last measurements was typically 2-3 hours.

At Imikpuk lakc, snow depth and snow-base temperature were also measured at $10 \mathrm{~m}$ intervals on 13,15 and 18 April in order to cxamine changes associated with the decrease in air temperatures that occurred during the investigation (Table 1). Records from the Barrow National Weather Scrvice (NWS) station show that air temperatures had been decreasing since 10 April and began to increase again on 19 April (NOAA, 1997).

The bulk density of the snow cover was measured by weighing a total of 48 samples of known volume $(100 \mathrm{~mL})$ extracted from the walls of 16 snow pits. Snow-temperature profiles were obtained using a digital thermometer and probe inserted at $0.05 \mathrm{~m}$ increments or less in the shaded wall of the same snow pits. At least two snow pits were investigated at cach lakc.

\section{ESTIMATING THE CONDUGTIVE HEAT FLUX THROUGH THE SNOW GOVER}

\section{Fourier heat-conduction equation}

Order-of-magnitude estimates of the conductive heat flux $\left(F_{\mathrm{a}}\right.$ in $\mathrm{W} \mathrm{m}^{-2}$ ) through the snow cover were obtained using the Fouricr heat-conduction cquation (Sturm and others, 1998):

$$
F_{\mathrm{a}}=\frac{-k_{\text {bulk }} \mathrm{d} T}{\mathrm{~d} z_{\text {snow }}} \approx \frac{-k_{\text {bulk }}\left(T_{s}-T_{b}\right)}{z_{\text {snow }}}
$$

where $k_{\text {bulk }}$ is the thermal conductivity of the snow cover in 


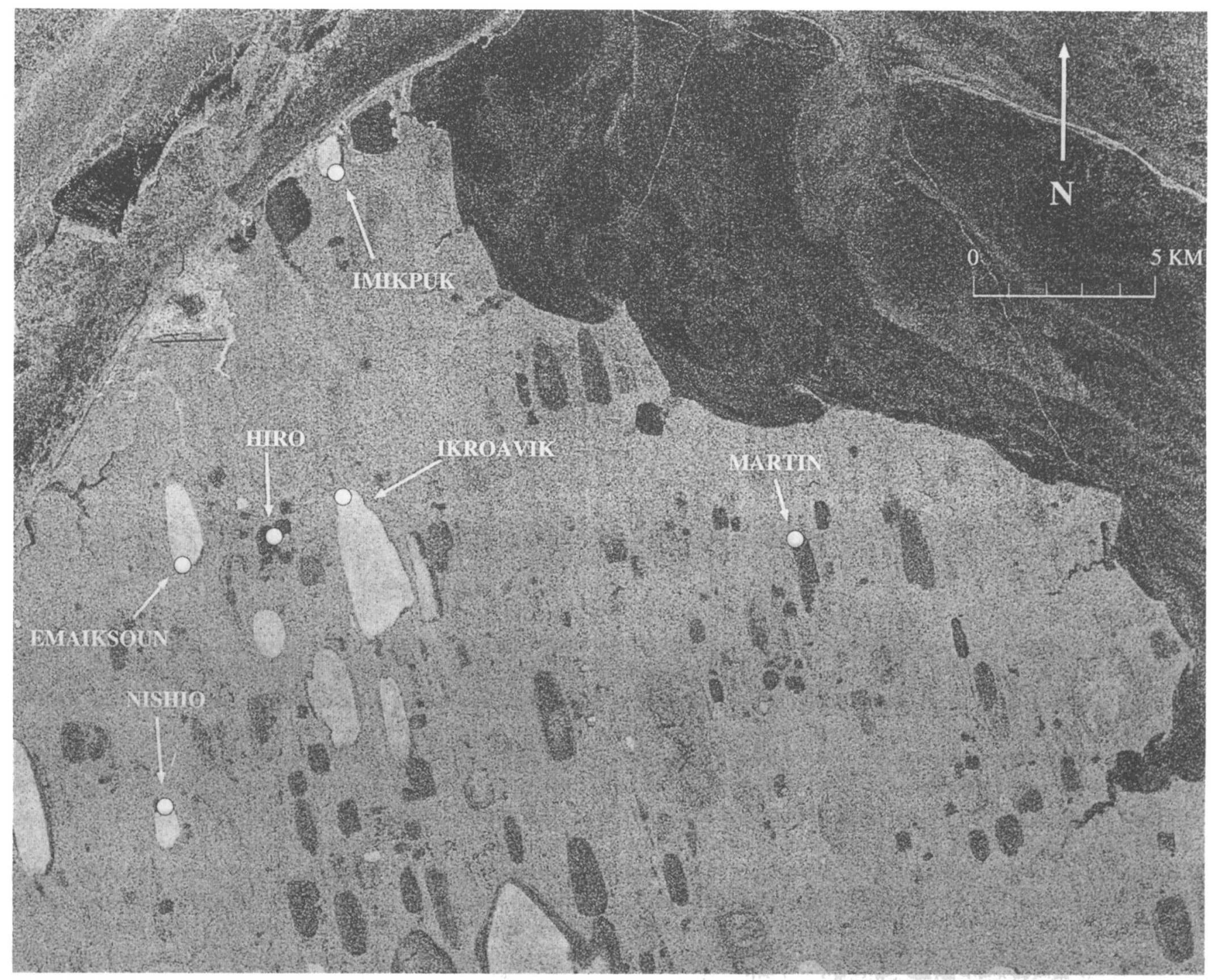

Fig. 2. Sub-scene of Figure 1. The white dots indicate lake/tundra sites where the snow cover was investigated during the period 1218 April 1997. The brightest signatures correspond to floating lake ice. The darker signatures correspond lo grounded ice, i.e. ice that has frozen completely to the lake bottom. Original SAR scene (C) ESA.

$\mathrm{W} \mathrm{m}^{-1} \mathrm{~K}^{-1}$ and $\left(T_{\mathrm{s}}-T_{\mathrm{b}}\right) / z_{\text {snow }}$ is the temperaturc gradient, where $T_{\mathrm{S}}$ is the snow surface temperature, $T_{\mathrm{b}}$ is the temperature at the base of the snow cover and $z_{\text {snow }}$ is the snow depth. $T_{\mathrm{B}}$ is the mean of the two snow-surface temperaturc values obtained at the beginning $\left(T_{1}\right)$ and end $\left(T_{2}\right)$ of each

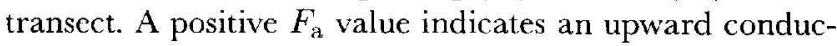
tive heat flux, and a negative valuc indicates a downward flux. 'This approach to the estimation of the conductive heat flux through the snow cover is the same as that described for Antarctic sea-ice floes (Massom and others, 1997, 1998; Sturm and others, 1998).

\section{Inputs and assumptions}

$k_{\text {bulk }}$ in Equation (1) was calculated according to

$$
k_{\text {bulk }}=\left(0.138-1.01 \rho+3.233 \rho^{2}\right),
$$

where $\rho$ is the snow density in $\mathrm{g} \mathrm{cm}^{-3}$ (Sturm and others, 1997). The snow on tundra, grounded ice and floating ice had mean bulk-density values of $0.353 \mathrm{~g} \mathrm{~cm}^{-3}(n=11)$, $0.352 \mathrm{~g} \mathrm{~cm}^{3}(n=26)$ and $0.404 \mathrm{~g} \mathrm{~cm}^{-3}(n=11)$, rcspectively. According to Equation (2), these fixed bulk-density values correspond to $k_{\text {bulk }}$ values of $0.185,0.183$ and $0.258 \mathrm{~W} \mathrm{~m}^{\mathrm{l}} \mathrm{K}^{\mathrm{l}}$, respectively.

$\Lambda$ detailed discussion of the snow bulk-density differ-

Table 1. Lake sampling locations, dates, transect surfaces and daily mean air temperatures at the Barrow $\mathcal{N W S}$ station

\begin{tabular}{|c|c|c|c|c|}
\hline Lake & Lacation & $\begin{array}{c}\text { Sampling date } \\
(1997)\end{array}$ & $\begin{array}{l}\text { Transect } \\
\text { surfaces }\end{array}$ & $\begin{array}{c}\text { Mean daily air } \\
\text { temperature } \\
\mathrm{C}\end{array}$ \\
\hline Imikpuk & $\begin{array}{c}71^{\prime} 19^{\prime} 33^{\prime \prime} \mathrm{N} \\
156^{\circ} 39^{\prime} 5^{\prime \prime} \mathrm{W}\end{array}$ & 12,13 April & $\begin{array}{l}\text { Tiundra, } \\
\text { grounded ice, } \\
\text { floating ice }\end{array}$ & -16.5 \\
\hline Ikroavik & $\begin{array}{l}71^{\circ} 14^{\prime} 41^{\prime \prime} \mathrm{N} \\
156^{\circ} 39^{\prime} 6^{\prime \prime} \mathrm{W}\end{array}$ & $14 A$ pril & $\begin{array}{l}\text { Tindra, } \\
\text { grounded ice, } \\
\text { floating ice }\end{array}$ & -18.0 \\
\hline Emaiksoun & $\begin{array}{l}71^{\circ} 13^{\prime} 57^{\prime \prime} \mathrm{N} \\
156^{\circ} 46^{\prime} 14^{\prime \prime} \mathrm{W}\end{array}$ & 15 ApriI & $\begin{array}{c}\text { Tundra, } \\
\text { grounded ice, } \\
\text { floating ice }\end{array}$ & -18.3 \\
\hline Martin & $\begin{array}{c}71^{\circ} 13^{\prime} 54^{\prime \prime} \mathrm{N} \\
156^{\circ} 18^{\prime} 45^{\prime \prime} \mathrm{W}\end{array}$ & 16 April & $\begin{array}{l}\text { Tundra, } \\
\text { grounded icc }\end{array}$ & -25.8 \\
\hline Nishio & $\begin{array}{c}71^{\circ} 11^{3} 35^{\prime \prime} \mathrm{N} \\
156^{\prime} 4557^{\prime \prime} \mathrm{W}\end{array}$ & 17 April & $\begin{array}{l}\text { Tundra, } \\
\text { grounded ice }\end{array}$ & 24.4 \\
\hline Hiro & $\begin{array}{c}71^{\circ} 14^{\prime} 20^{\prime \prime} \mathrm{N} \\
156^{\circ} 42^{\prime} 18^{\prime \prime} \mathrm{W}\end{array}$ & 18 April & $\begin{array}{l}\text { Tundra, } \\
\text { grounded ice }\end{array}$ & -27.2 \\
\hline
\end{tabular}


Table 2. Summary of snow surface lemperatures and consequences for the estimation of $F_{\mathrm{a}}$

\begin{tabular}{|c|c|c|c|c|c|c|c|c|}
\hline \multirow[t]{2}{*}{ Lake, date } & $T_{i}$ & $T_{\text {treat } n}$ & $\tau_{2}$ & $F_{a 1}$ & $F_{\text {dumean }}$ & $F_{\alpha 2}$ & $\Delta$ & $n$ \\
\hline & ${ }^{\supset} \mathrm{C}$ & ${ }^{\circ} \mathrm{C}$ & ${ }^{\circ} \mathrm{C}$ & $W_{m}{ }^{2}$ & $\mathrm{~W} \mathrm{~m}^{-2}$ & $\mathrm{Wm}^{-2}$ & $\%$ & \\
\hline Imikpuk, 12 April & -12.7 & -13.65 & -14.3 & 10.33 & 14.00 & 17.68 & +71 & 321 \\
\hline Imikpuk, 13 April & $-11: 2$ & 14.25 & -14.3 & 0.01 & 0.05 & 0.09 & +900 & $58^{*}$ \\
\hline Imikpuk, 13 April & -14.2 & -14.25 & -14.3 & 6.85 & 6.99 & 7.13 & +4 & $38^{\dagger}$ \\
\hline Ikroavik, $14 \Lambda$ pril & -14.6 & -16.05 & -17.5 & 2.36 & 3.79 & 5.22 & +54 & 16] \\
\hline Emaiksoun, 15 April & -17.8 & -17.75 & -17.7 & 7.18 & 7.13 & 7.07 & 1.5 & 95 \\
\hline Imikpuk, 15 April & -20.6 & 20.4 & -20.2 & 13.30 & 12.89 & 12.48 & -0.06 & $38^{\dagger}$ \\
\hline Martin, 16 April & -27.0 & -25.0 & -23.0 & 6.46 & 5.11 & 3.76 & -41 & 94 \\
\hline Nishio, $17 \Lambda$ pril & -26.7 & -24.5 & -22.3 & 10.70 & 8.82 & 6.93 & -35 & 78 \\
\hline Hiro, 18 April & -27.1 & -25.9 & -24.7 & 5.75 & 4.75 & 3.73 & $3 \overline{5}$ & 81 \\
\hline Imikpuk, 18 April & -27.0 & 26.5 & -26.0 & 23.29 & 22.07 & 20.84 & -10 & $38^{\dagger}$ \\
\hline
\end{tabular}

Notes: $T_{1}$ and $T_{2}$ are the snow-surface temperature measurements made at the beginning and end of each transect, respectively. $T_{\text {rteran }}$ is the mean of $T_{1}$ and $T_{2}, F_{n 1}$ and $F_{\mathrm{a} 2}$ are the mean flux values for each transect estimated using only $T_{1}$ and $T_{2}$ to calculate the temperature gradient in the snow, respectively. $F_{\mathrm{a} \text { mean }}$ is the mean flux calculated using the mean of $T_{1}$ and $T_{2} . \Delta$ is the difference between $F_{\mathrm{a} 1}$ and $F_{\mathrm{a} 2} . n$ is the mumber of snow-depth and snow/ice interface temperature measurements.

* Measurements on lundra only.

+ Measuremerits made at $10 \mathrm{~m}$ intervals.

ences is beyond the scope of this paper. However, they do match observations we have made during previous latewinter visits to the lakes. Then, the snow on the tundra had a well-developed basal depth-hoar layer, hence the lower bulk density of the snow cover, while the snow on floating ice, in particular, was composed entirely of hard wind-slab, hence the higher bulk density.

The use of a minimal number of snow-surface temperature measurements at the sampling transects assumes that those values are representative of the snow cover as a whole at the time of each measurement. This is a reasonable assumption according to recent experience at the SHEB $\Lambda$ ice camp in the Arctic Ocean, where the surface temperature variation was typically $\leq 0.5^{\circ} \mathrm{C}$ over $1 \mathrm{~km}$ distances and 15 min time intervals for uniform ice conditions (personal communication from J. Maslanik, 1998).

It is assumed that the heat fluxes through the snow and ice are vertical. Sturm and others (1998) considered this to be rcasonable. The calculation of $F_{\mathrm{a}}$ according to Equation (1) assumes also that the snow-temperature gradients are lincar, although these rarely occur and most snow-temperature profiles are concave (Sturm, 1991). Temperature profiles in the snow on tundra, grounded ice and floating ice at each of the six lakes were concave and, as air temperatures decreased during the course of the 6 day investigation, the temperature difference between the top and bottom of the snow cover increased.

T'he $F_{\mathrm{a}}$ calculations also assume that the computed tcmperature gradients are approximately equal to steady-state gradients and therefore proportional to the heat flux (Sturm and others, 1998). To obtain some measure of the effect of transient temperature variations, mean $F_{\mathrm{a}}$ values for each transect were estimated using the two individual snow-surface tempcrature measurements $\left(T_{1}\right.$ and $\left.T_{2}\right)$ made at the beginning and end of each transect. The results are summarized in Table 2. A very large increase in the mean $F_{\mathrm{a}}$ occurred on the tundra at Imikpuk lake, but it is meaningless inasmuch as the fluxes were cxtemcly low in any case. At the other locations there were moderate changes in the mean $F_{a}$, but in all cases the values remained positive.

Wc recognize that the assumption of linear, steady-state temperature gradients introduces errors into the estimation of $F_{i b}$, and that the $F_{\mathrm{a}}$ estimates represent only the time that measurements were made at the individual sampling transects. However, the fact that we made measurements during a 6 day period of decreasing air temperatures means that the $F_{\mathrm{a}}$ estimates are conservative on any given day, i.e. if we had returned to a particular sampling transect on a later day during the measurement period, the fluxes would have been greater, as the air temperatures had decrcased. This is particularly true of the flux estimates through snow on floating icc, as it was sampled primarily in the first half of the study period when the air temperatures were higher and the fluxes thereforc lower than they would have been during the second half of the study period. There is less bias in the $F_{\mathrm{a}}$ estimates through the snow on the tundra and grounded icc, as they werc sampled on each of the 6 days. Errors in the $F_{\text {a }}$ estimates are also minimized by the relatively large number of measurements (Table 2), which reduces the standard error of the mean flux values. As the data will show, there were significant fluxes from the land to the atmosphere, and order-of-magnitude differences between the fluxes from the floating ice and those from the grounded ice and tundra.

\section{Estimated conductive heat-flux variations}

At the three lakes where the snow cover on tundra and floating ice was sampled, there was a strong contrast between the conductive heat flux through the tundra snow and that through the snow on the floating ice, with intermediate values on the grounded ice margin (Fig. 3a and c). At the three lakes where the transects included only tundra snow and snow on grounded ice, the contrast between conductive heat flux from tundra and that from icc was much less than at the other lakes (Fig. 3b). $F_{\mathrm{a}}$ values of $>60 \mathrm{~W} \mathrm{~m}^{-2}$ at Imikpuk lake (Fig. 3c) occurred where the snow was particularly thin.

The heat fluxes increased as the air temperatures decreased during the study period, as observed at the Imikpuk lake monitoring site (Fig. 3c). The greatest relative increases occurred through the tundra snow, but the heat flux through the snow on floating ice always remained at least one order of magnitude higher than that through the tundra snow (lable 3). The heat flux through the snow on grounded icc was always a little higher than that through the tundra snow, but also an order of magnitude lower than that through the snow on floating ice (Table 3 ). The increase 


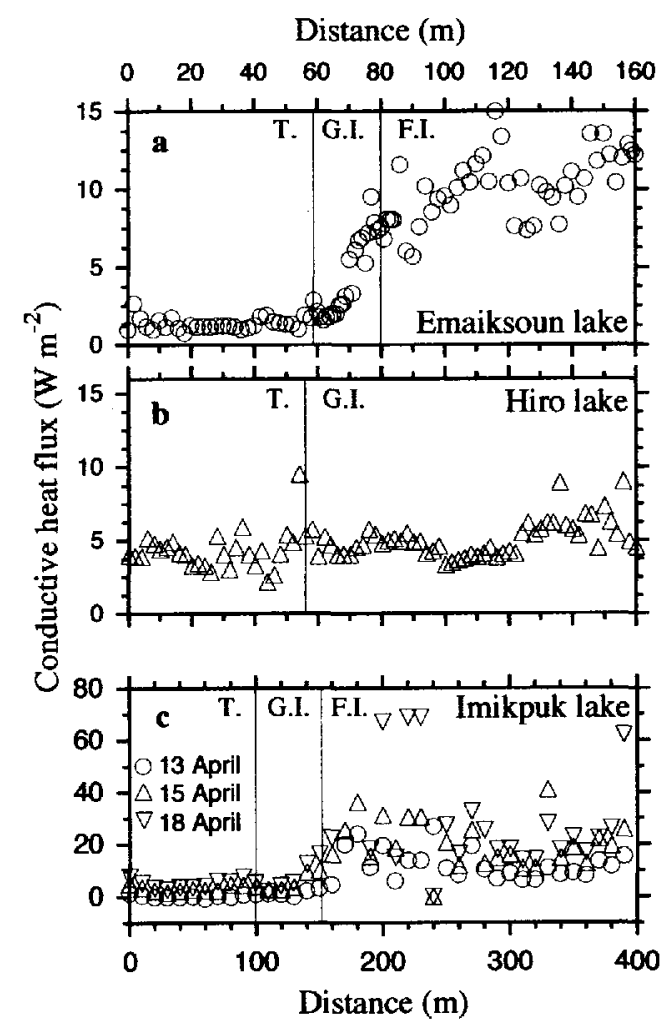

Fig. 3. Estimaled $F_{\mathrm{a}}$ values along the transects at Emaiksoun, Martin and Imikpuk lakes. T., G.I. and F.I. are tundra, grounded ice and floating ice, respectively.

in $F_{\mathrm{a}}$ at Imikpuk lake was due to the decrease in air temperatures during the measurement period rather than any changes in the snow depth. The latter remained constant during the period of investigation, as measured at Imikpuk lake on 13,15 and 18 April when the mean snow depth $(0.19 \mathrm{~m})$ and the standard error $(0.02)$ were the same each day.

The differences in heat flux through the snow on tundra, grounded ice and floating ice as observed at Imikpuk lake (Fig. 3c), for example, were a characteristic of the dataset for the entire study period, as shown by the data distributions in Figure 4. On average, the mean heat flux through snow on grounded ice was almost four times greater than that through tundra snow, while the mean heat flux through the snow on floating ice was an order of magnitude greater than that through the tundra snow. The low $F_{\text {a }}$ values for the tundra snow are similar to those determined from heat-flux plate measurements and independent calculations of tundra fluxes (Hinzman and others, 1991a, b; Sturm and Holmgren, 1994). The $F_{\mathrm{a}}$ distributions for tundra ( $\left.F i g .4 a\right)$ and grounded ice (Fig. 4b) are bimodal because they are based on measurements made during the entire 6 day study period, which was characterized by much lower temperatures on days 4-6 (Table 1), whereas, as noted previously,

Table 3. Mean estimated $F_{\mathrm{a}}$ values $\left(\mathrm{Wm}^{2}\right)$ for tundra, grounded ice and floating ice at Imikpuk lake on three different days

\begin{tabular}{cccc}
\hline Date & Tundra & Grounded ice & Floating ice \\
\hline 13 April 1997 & 0.06 & 1.4 & 12.1 \\
15 April 1997 & 3.2 & 5.6 & 20.0 \\
18 April 1997 & 4.9 & 8.0 & 37.5 \\
\hline
\end{tabular}

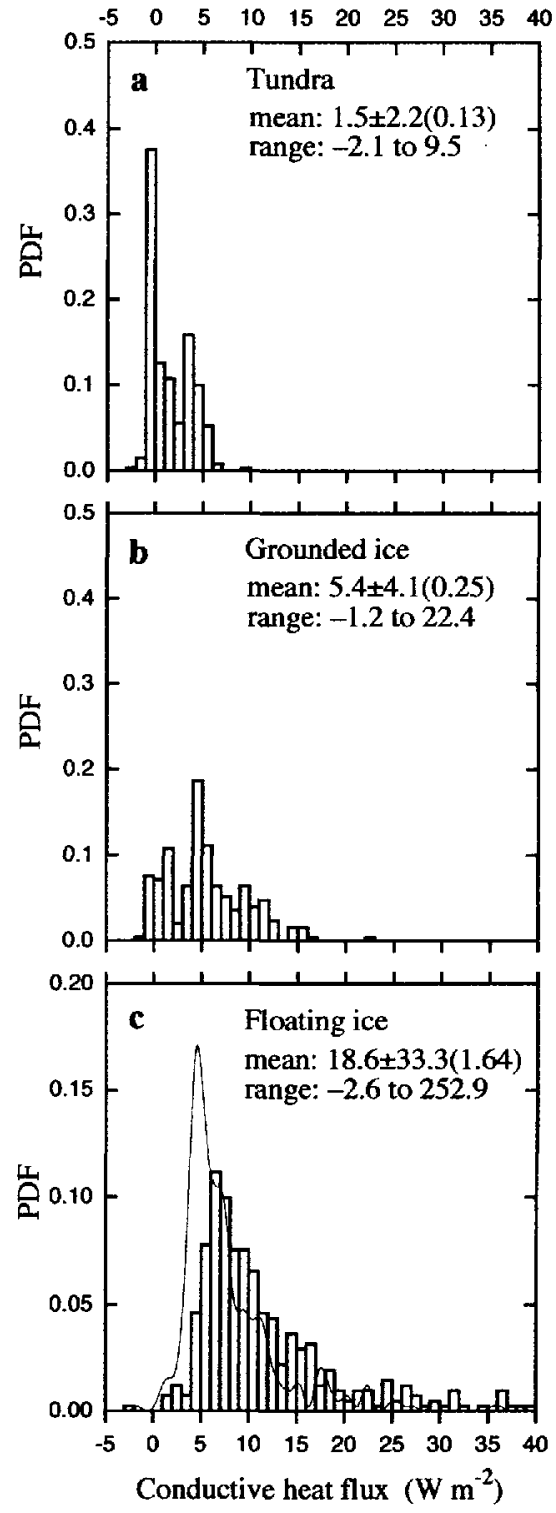

Fig. 4. Probability density functions (PDFs) of $F_{\mathrm{a}}$ at each measurement point on the transects on (a) tundra, (b) grounded ice and (c) floating ice at all the lakes during the period 1218 April 1997. A 1 standard deviation value (and a 1 standard error in parentheses) is given with the mean value in each plot. The $x$ axis on each graph has the same range, for ease of comparison, but this means that a fere values of $>40 \mathrm{Wm}^{-2}$ on floating ice have been excluded. The hairline curve in (c) is the $F_{\mathrm{a}}$ PDF calculated for the snow on floating ice using the thermal conductivity value for snow with a mean bulk density of $0.352 \mathrm{~g} \mathrm{~cm}^{-3}$. This dataset has a mean $F_{\mathrm{a}}$ value of $13.2 \pm 23.6 \mathrm{~W} \mathrm{~m}^{2}$ and a range of 1.8 to $179.0 \mathrm{Wm}^{-2}$.

most of the measurements on floating ice were made during the warmer days $1-3$ (Table 1 ).

The heat fluxes through the snow on floating ice were also calculated for snow with a mean bulk density of $0.352 \mathrm{~g} \mathrm{~cm}^{3}$, i.e. the same as that of the snow on tundra and grounded ice, and thus lower thermal conductivity. The resultant $F_{\mathrm{a}}$ values (Fig. $4 \mathrm{c}$ ) are lower than those calculated using a mean bulk density of $0.404 \mathrm{~g} \mathrm{~cm}^{-3}$ (the value originally used to represent snow on floating ice), but they are still an order of magnitude greater than those through tundra snow (Fig. 4a and b).

Using the same field-based method for estimating conductive heat fluxes through the snow cover on Antarctic 
first-year ice revealed typical values of $5-15 \mathrm{~W} \mathrm{~m}^{-2}$ in the Weddell Sea (Massom and others, 1997), 5-20 $\mathrm{W} \mathrm{m}^{-2}$ in the East Antarctic pack ice (Massom and others, 1998) and 3$9 \mathrm{~W} \mathrm{~m}^{-2}$ in the Ross, Amundsen and Bellingshausen Seas (Sturm and others, 1998). The North Slope $F_{\text {a }}$ values are also similar to those determined by measurement and numerical modelling at Ice Station Weddell, Antarctica, where $F_{\mathrm{a}}$ varied between 0 and $30 \mathrm{~W} \mathrm{~m}^{2}$ during a 100 day period in autumn; the highest values occurred early in the period when the temperature gradients were at a maximum and the snow/ice interface was flooded with sea water (Lytle and Ackley, 1996). This comparison of point measurements suggests that the Alaskan North Slope is a source of energy on a par with the south polar ocean, at least. Later we show that the same applies to the area-weighted heat flux when compared to that from the Arctic Ocean.

\section{NUMERICAL MODELING OF CONDUCTIVE HEAT FLUXES}

\section{Introduction}

The estimated heat fluxes indicate that there are significant differences between the heat flow from the tundra and that from lakes on the Alaskan North Slope at the end of winter. In this section we describe a two-dimensional model that was run in one-dimensional mode in order to simulate the conductive heat fluxes and to explain the flux differences between the tundra, grounded ice and floating ice. 'The simulations were conducted for five different cases (Fig. 5): (1) tundra; (2) a lake that is $3 \mathrm{~m}$ deep and thus exceeds the maximum winter ice thickness (previous investigations indicate that lakes $>2 \mathrm{~m}$ deep typically do not freeze to the bottom: Brewer, 1958); and (3) three shallow lakes (0.4, 0.8 , $1.2 \mathrm{~m}$ deep) where the ice would freeze completely to the lake bottom at different times during winter. Each case can be thought of as a point along a sampling transcet that begins on tundra and then crosses onto a lake where the water becomes progressively decper with distance away from the lake edge.

\section{Model description}

A finite-element heat-conduction model (Gosink and Ostcrkamp, 1990), which is a modified version of Guymon and Hromadka's (1977) and Guymon and others' (1984) model, was further modified for the simulation of a coupled
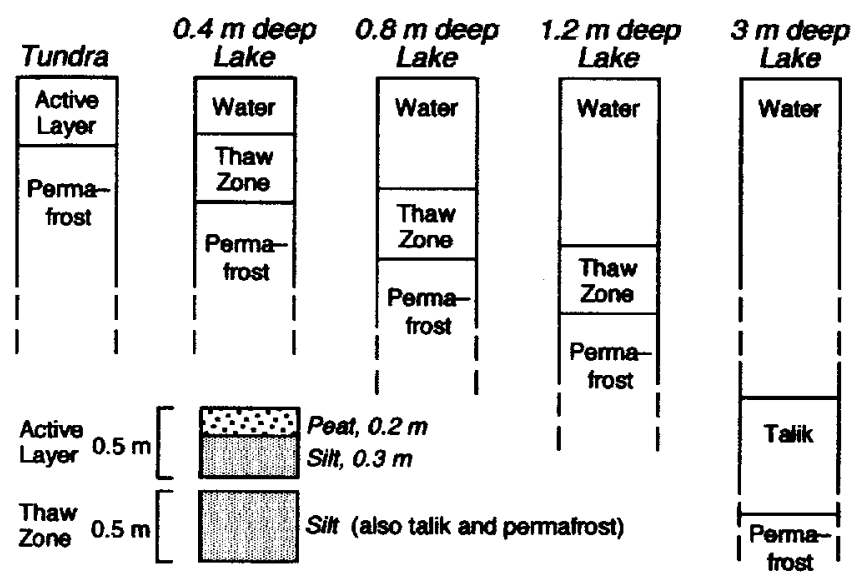

Fig. 5. Diagrammatic representation of the five cases simulated using the numerical model of the coupled snow/ ice/water/soil system. snow/ice/water/soil system. If there is no lateral heat flow, the appropriate one-dimensional heat-conduction equation in the snow/ice/water/soil system is

$$
C_{\mathrm{v}} \frac{\partial T}{\partial t}=\frac{\partial}{\partial z}\left(K \frac{\partial T}{\partial z}\right),
$$

where $t$ is the time in seconds, $z$ is the position coordinate measured from the surface downward in meters, $T$ is the temperature in ${ }^{\circ} \mathrm{C}, K$ is the thermal conductivity in $\mathrm{W} \mathrm{m}{ }^{-1} \mathrm{~K}^{-1}$, and $C_{\mathrm{v}}$ is the volumetric heat capacity in $\mathrm{J} \mathrm{m}^{-3} \mathrm{~K}^{-1}$. When unfrozen water or brine is present in the permafrost, the lefthand side of Equation (3) is modified to include the enthalpy change associated with a change in $T$ (Gosink and Osterkamp, 1990):

$$
\Delta H=\int C_{\mathrm{v}} \mathrm{d} T+\int L(T) \mathrm{d} \theta_{\mathrm{u}}
$$

where $H$ is the composite enthalpy change of the snow/ice water/soil system, $\theta_{\mathrm{u}}$ is the volume fraction of unfrozen water or brine, and $L$ is the volumetric latent heat of fusion.

The modified model includes up to six different types of materials, individually or in combination, such as snow, ice, water, peat, silt, sand and gravel. Latent heat is included by either of two methods: that of Osterkamp (1987), which uses an apparent specific heat with latent heat as a source distributed over a given temperature range; or the method developed by O'Neill (1983), which employs a latent-heatcontent "spike" at a given frcezing temperature. The O'Neill method, in which the phase change is completed at a given freezing temperature, was used for snowmelt, lake-ice growth and decay, and freezing and thawing of the peat laycr. For this study, freezing was assumed to begin at a temperature of $0^{\circ} \mathrm{C}$. The thermal properties of the soil layers were determined during the calculations, depending upon soil temperatures and the position of the phase boundary.

On the coastal plain of the Alaskan North Slope, the active layer on the tundra surrounding the lakes is typically 0.4-0.5 $\mathrm{m}$ deep (Brown and Johnson, 1965; Nelson and others, 1997; Zhang and others, 1997). The simulation used a $0.5 \mathrm{~m}$ deep active layer composed of a $0.2 \mathrm{~m}$ deep layer of peat overlying a $0.3 \mathrm{~m}$ deep layer of silt (Fig. 5). Below lakes $<2 \mathrm{~m}$ deep is a $0.3-0.7 \mathrm{~m}$ thick thaw zone interposed between the water and the permafrost. The thaw zone forms each summer and freezes each winter (Brewer, 1958; Coyne and Kelley, 1974). The simulated thaw zone in the lakes was composed of a $0.5 \mathrm{~m}$ thick layer of silt only. A thaw-zone thickness of $0.5 \mathrm{~m}$ was chosen, as it is in the middle of the range of observed thicknesses. Lakes deeper than $2 \mathrm{~m}$ develop a perennial thaw bulb, also known as a talik (Lachenbruch and others, 1962). In the simulation, the bottom of the talik was $15 \mathrm{~m}$ below the surface. The permafrost beneath the tundra active layer, the shallow-lake thaw zones and the talik was composed only of silt (Fig. 5).

Snow cover was included as an additional layer, with thermal conductivity calculated from Equation (2). A bascline time series of daily snow-depth data was obtained from the Barrow NWS station and proportionally adjusted according to measurements we made in the field. This was done because the NWS measurements generally underestimate the true precipitation totals on the North Slope (Benson, 1982). For example, for the interval 13-18 April 1997, the mean snow depth measured on the tundra was $0.33 \mathrm{~m}$, while that at the Barrow NWS station was $0.22 \mathrm{~m}$ : a ratio of 1.5 . To allow for these differences, the daily tundra 
snow depth used in the model was the daily NWS snow depth multiplied by 1.5. The same method was used to model the daily snow thickness over grounded ice and floating ice where the average snow depths measured were 0.26 and $0.17 \mathrm{~m}$, respectively. A similar "data-assimilation" mode was used with respect to the ice thickness. Running the model in this mode allows it to include the ice-thickness measurements, such that a model run leads to a simulated ice thickness that is equal to the measured ice thickness during the observation period $(1.53 \mathrm{~m})$.

The upper boundary was set at either the snow, ice, water or soil surface, as appropriate. The daily mean air temperature measured at the Barrow NWS station was used as the upper boundary condition. This is not ideal, as the snow-surface temperature is usually lower than the air temperature due to the high albedo and emissivity of the snow surfacc, both of which tend to cool the snow surface (Weller and Holmgren, 1974). However, there is no winter-long snow-surface temperature record available to run the model. In any event, the result of using air temperatures is an underestimation of the heat flux through the snow, in keeping with the conservative estimates based on the field measurements.

The lower boundary was located $15 \mathrm{~m}$ below the surface, deep enough to ensurc no significant effect on tcmpcratures at shallower depths. Over the course of many years the depth could change, but since we are investigating only winter $1996-97$ it is appropriate to use a single, constant value for the lower boundary depth. Field measurements near Barrow indicate that the permafrost temperature $15 \mathrm{~m}$ below the surface is about $-9^{\circ} \mathrm{C}$ (Lachenbruch and others, 1962; Lachenbruch and Marshall, 1986). Field measurements (Lachenbruch and others, 1962) and numerical modeling (Zhang and Jeffries, unpublished results) show that a talik with a temperature close to $0^{\circ} \mathrm{C}$ develops under lakes $>2 \mathrm{~m}$ deep. The modeling results also show that for a lake $<2$ m deep, the permafrost temperature at $15 \mathrm{~m}$ depth varies between $-4^{\circ}$ and $-7^{\circ} \mathrm{C}$. Thus, constant temperatures of $9^{\circ}$, $-5^{\circ}$ and $0^{\circ} \mathrm{C}$ were chosen for the lower boundary condition of the tundra, three shallow lakes $(<1.2 \mathrm{~m}$ deep) and the deep lake $(3.0 \mathrm{~m})$, respectively.

The snow/ice/water/soil system was divided into 24 layers when snow was present, and 23 layers when snow was absent. The layer thickness varied from $0.2 \mathrm{~m}$ near the upper boundary to $1.0 \mathrm{~m}$ near the lower boundary. The simulation began on 1 August 1996 and the time-step of the computations was 1 day.

\section{Results of simulating conductive heat fluxes through the snow cover}

The simulated conductive heat fluxes through the snow cover on tundra, floating ice and the three different grounded-ice cases for the period of the field investigation are presented in Figure 6. The mean values of the cstimated fluxes and simulated fluxes are summarized in Table 4 . The simulated values are higher than the estimates for tundra and grounded ice, and lower than the estimate for floating ice. These differences might be reduced by forcing the simulations with hourly air temperatures, or snow surface temperatures if they were available, and improved scalings of the NWS snowdepth data, and by selecting different material properties and proportions in the active-layer and thaw zones.

Table 4. Comparison of the mean estimated $F_{\mathrm{a}}$ values $\left(\mathrm{Wm}^{-2}\right)$ and those simulated by the numerical model for tundra, grounded ice and floating ice

\begin{tabular}{lccc}
\hline & Tundra & Grounded ice & Floating ice \\
\hline Mean estimated heat flux & 1.5 & 5.4 & 18.6 \\
Mean simulated heat flux & 2.6 & 9.4 & 15.2 \\
\hline
\end{tabular}

Despite the differences, the model simulates very well both the relative differences between tundra, grounded ice and floating ice, and the magnitudes of the fluxes for cach substrate. The lowest fluxes occur through the tundra snow (Fig. 6a), and the highest fluxes through the snow on floating ice (Fig. 6c). Intermediate fluxes occur through the snow on the grounded ice, and those fluxes increase as lake depth increases (Fig. 6b). The highest fluxes occur on the floating ice regardless of the choice of snow thermal conductivity (Fig. 6c). The simulated fluxes increase as the air temperature decreases (Fig. 6a), and the increase in simulated heat flux from the floating ice (Fig. 6c) is of the same order of magnitude as that observed at Imikpuk lake during the field investigation (Fig. 3c).

Figure 7 illustrates the simulated conductive heat fluxes through the snow cover for each of the five cases (Fig. 5) for
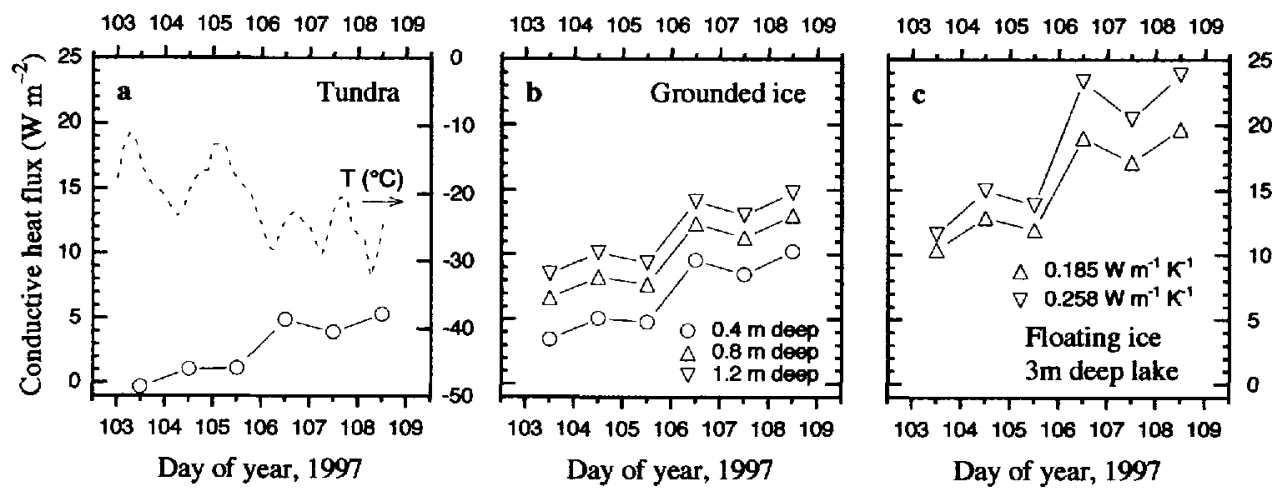

Fig. 6. Simulated $F_{\mathrm{a}}$ values for each of the five cases illustrated in Figure 5 as a function of time during the field investigation, 12 18 April 1997 (days 103-109). The air temperature measured at the Barrow NWS station used as input to drive the model simulations is also shown in (a). Two curves are given in (c) to show the heat flux through snow cover of different bulk density and thus different thermal conductivity $\left(0.185\right.$ and $\left.0.258 \mathrm{~W} \mathrm{~m}^{-1} \mathrm{~K}^{-1}\right)$. The simulations in $(a)$ and $(b)$ were run only with a snow thermal conductivity of $0.185 \mathrm{~W} \mathrm{~m}^{1} \mathrm{~K}^{1}$. 


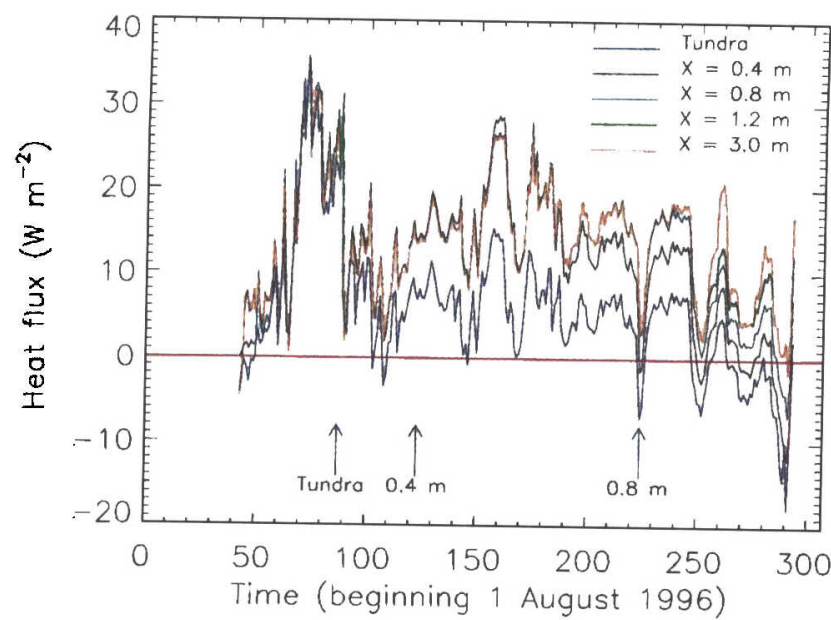

Fig. 7. Simulated $F_{\mathrm{a}}$ values for the entire winter for each of the five cases ( $X$ is the lake depth) illustrated in Figure 5. The field investigation occurred between days 255 and 261 when the simulation shows increasing fluxes. Days 50, 100, 150, 200,250 and 300 correspond to 19 September, 8 November, 28 December, 16 February, 7 April and 27 May, respectively. The vertically oriented arrows along the bottom of the graph denote the times when the active layer on the tundra froze completely to the permafrost, and the thaw zones beneath 0.4 and $0.8 m$ deep water froze completely to the permafrost. The thaw zone beneath $1.2 \mathrm{~m}$ of water did not freeze complelely in this simulation.

the entire winter of 1996-97. The graph shows that we could have conducted the field investigation at almost any time prior to or after the field investigation and obtained the same result, i.e. significant differences in conductive heat flux through the snow cover on tundra, grounded ice and floating ice. The fact that these differences are maintained throughout the winter in the simulation suggests that the flux estimates based on the field measurements have wide applicability and that the effects of transient snow-surface temperature variations are minor. Figure 7 also indicates that, although high in their own right, the conductive heat fluxes during the field investigation were $2-3$ times lower than they had been during most of the winter.

Figure 7 also helps to explain the differences in conductive heat flux from the tundra, grounded ice and floating ice. In lakes where the water depth exceeds the maximum winter ice thickness, roughly $2 \mathrm{~m}$, the large heat fluxes occur because a body of relativcly warm water remains below the growing ice, which has a relatively high thermal conductivity. On the tundra, on the other hand, it is known from previous investigations that the active layer becomes completely frozen (Brown and Johnson, 1965; Brown, 1969). In the simulations, this occurred on 26 October 1996 (day 93; Fig. 7). Subsequently, the frozen active layer, which has a relatively low thermal conductivity, continues to cool as heat is removed from the soil and released to the atmosphere, but it rarely becomes isothermal (Osterkamp and Romanovsky, 1997). Consequently, even towards the end of winter, there is an energy flux from the soil to the atmosphere. It is two orders of magnitude greater than the geothermal heat flux $\left(0.0565 \mathrm{~W} \mathrm{~m}^{-2}\right.$ : Lachenbruch and others, 1982), but an order of magnitude lower than that through the snow on floating ice.

Where the water depth is less than the maximum winter ice thickness, the complete freezing of the annual thaw zone beneath a lake will occur later than the active layer on the land, as the submerged thaw zone cannot begin to frecze until the growing lake ice comes into contact with the lake bottom. Furthermore, the greater the water depth in the ice grounding zone, the greater the delay in onset and complete freezing of the submerged thaw zone. In the simulations for the 0.4 and $0.8 \mathrm{~m}$ deep lakes, the thaw zones became completely frozen on 1 December 1996 (day 122; Fig. 7) and 12 March 1997 (day 224; Fig. 7), respectively. In the simulation for a $1.2 \mathrm{~m}$ deep lake, the thaw zone did not freeze completely and a $0.1-0.15 \mathrm{~m}$ thick layer remained unfrozen at the end of winter; consequently, the flux values were higher than those at the shallower lakes (Fig. 6b).

\section{AREA-WEIGHTED CONDUGTIVE HEAT FLUX}

\section{Areal fractions of tundra, grounded ice and floating ice}

On the basis of the good agreement between the simulated and estimated $F_{\text {a }}$ values, we use the estimated fluxes to calculate the area-weighted heat flux for six areas on the Alaskan North Slope near Barrow (Fig. 1). Spaceborne SAR data wcre used to determine the areal fractions of tundra, grounded ice and lake ice at the time of the field investigation.

For reasons described in detail elsewhere (e.g. Weeks and others, 1978), floating ice on these shallow lakes has a bright signature due to strong returns to the radar, while the grounded ice has a dark signature due to low returns to the radar. Thus, as noted earlier, the many small, bright features in Figure 1 indicate that extensive areas of ice remained afloat across a broad swath of the Alaskan North Slope in late winter 1997. The different signatures of floating and grounded ice are particularly evident in Figure 2.

ERS-2 SAR data (Figs 1 and 2) of the study area were obtained on 19 April 1997, the day after we finished making observations. Based on the signature differences between tundra, grounded ice and floating ice, a thresholding technique was used to determine the areal fraction of each type in six different areas (Fig. 1). Each of the six areas is quite small relative to the full SAR image (Fig. 1) because of image analysis software limitations. Each area was selected on the basis of qualitative differences in lake size, density (number per unit area), and extent of grounded and floating ice. The total area of each sampling area, and the areal fractions of tundra, grounded ice and floating ice are summarized in Table 5.

Table 5. Summary of sampling areas and areal fractions of tundra, grounded ice and floating ice used to calculate the area-weighted conductive heat flux. The sum of the grounded and floating ice fractions is the areal fraction of lakes

\begin{tabular}{ccccc}
\hline Area & Total area & Tundra & Groundedice & Floating ice \\
& $\mathrm{km}^{2}$ & $\%$ & $\%$ & $\%$ \\
\hline A & 506 & 69.4 & 10.9 & 19.7 \\
B & 445 & 72.2 & 12.0 & 15.8 \\
C & 419 & 75.6 & 7.9 & 16.5 \\
D & 463 & 72.2 & 13.3 & 14.5 \\
E & 578 & 75.3 & 13.4 & 11.3 \\
F & 918 & 66.0 & 17.6 & 16.4 \\
\hline
\end{tabular}




\section{Area-weighted heat losses in areas A-F}

Using the areal fractions for each of the six sampling arcas

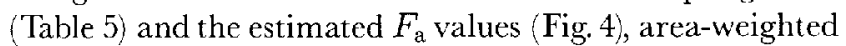
heat fluxes $\left(F_{\text {weighted }}\right)$ were calculated according to

$$
A_{\mathrm{g}} F_{\mathrm{g}}+A_{\mathrm{f}} F_{\mathrm{f}} \text { (grounded ice }+ \text { floating ice) }
$$

$$
A_{\mathrm{t}} F_{\mathrm{t}}+A_{\mathrm{g}} F_{\mathrm{g}}+A_{\mathrm{f}} F_{\mathrm{f}}
$$

$$
\text { (tundra }+ \text { grounded ice }+ \text { floating ice) }
$$

where $A$ is the areal fraction of tundra $(t)$, grounded ice $(g)$ and floating ice $(f)$ (from Table 5) and $F$ is the estimated conductive heat flux for each surface. $F_{\text {weighted }}$ was calculated using the mean $F_{\text {a }}$ valuc for cach surface, and the \pm 1 standard deviation values of the mean for each surface; for example, for tundra the $F_{\mathrm{t}}$ values are -0.7 and $3.7 \mathrm{~W} \mathrm{~m}^{-2}$ (i.e. $1.5 \pm 2.2 \mathrm{~W} \mathrm{~m}^{-2}$; Fig. $4 \mathrm{a}$ ).

The heat fluxes have been calculated in this way as it provides some indication of the possible range of values during the sampling period that might have arisen from: (a) transient, diumal and day-to-day variability; (b) spatial variability in snow characteristics and weather, i.e. the Barrow observations and measurements might not have been representative of all the selected areas; (c) potential variations in snow thermal conductivity for any given snow-density value (Sturm and others, 1997, fig. 6); and (d) the fact that we did not sample snow on floating ice during the second half of the study period when the air temperatures were at their lowest and the heat flux from the floating icc would have been higher.

The number and size of lakes in each of the sampling areas varies (Fig, 1), but there are only minor differences between each area in terms of the areal fractions of lakes, floating ice and grounded ice (Table 5). Consequently, there arc only small differences in the area-weighted heat flux from each sampling area, as indicated by the bars in Figure 8 , and each sampling area alone provides a reasonable estimate of heat loss from a much larger area. The areaweighted heat fluxes from the ice vary between 9.8 and

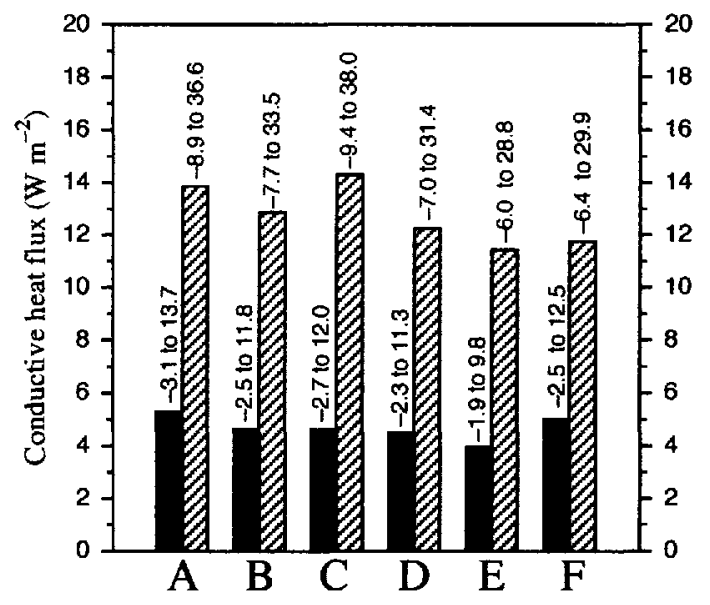

Fig. 8. Variability of area-zeeighted $F_{\mathrm{a}}$ values in areas $A-F$ (see Fig. 1) calculated using the estimated mean $F_{\mathrm{a}}$ values in Figure 4. The solid bars represent the area-weighted fluxes from the entire area (tundra and lakes). The cross-hatched bars represent the area-weighted losses from the lakes only (floating ice and grounded ice). The range of values at the top of each bar represents the area-weighted fluxes calculated using the \pm 1 standard deviation flux values for each substrate in Figure 4.
$13.8 \mathrm{~W} \mathrm{~m}^{-2}$, and those from the ice plus tundra vary between 3.9 and $5.3 \mathrm{~W} \mathrm{~m}^{-2}$.

Similar area-weighted conductive heat fluxes have been calculated for the Arctic Occan at the same time of year. For example, in April at the AIDJEX manned array in the Beaufort Sea, Arctic Ocean, the area-weighted conductive heat flux through the ice to the snow/ice interface for all ice thicknesses was $7.0 \mathrm{~W} \mathrm{~m}^{-2}$, while that through the thickest ice $\left(>0.8 \mathrm{~m}\right.$ ) was $1.2 \mathrm{~W} \mathrm{~m}^{-2}$ (Maykut, 1982). The conductive heat fluxes through the snow cover at AIDJEX would have been slightly lower than those through the ice because snow has a lower thermal conductivity than ice.

Negative flux values, i.e. heat gains, are indicated (Fig. 8) when the heat flux is calculated using -1 standard deviation

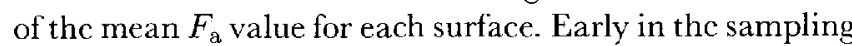
period, negative heat fluxes were calculated for a few points along the transects where the temperatures at the snow surface were higher than those at the base of the snow cover. However, it is unlikely that the area-weighted heat fluxes were negative for any significant length of time, if at all, during the sampling period. $\Lambda$ s Table 2 shows, the mean flux values for each transect remained positive under all the measured snow-surface tempcrature conditions. More significant than the negative values is the range, which indicates that the area-weighted fluxes can vary significantly and reach high values.

Zhang and others (1996) suggested that the relatively high temperatures that characterize the winter climate along the Arctic coast of the Alaskan North Slope are due to the proximity to the Arctic Ocean and its high heat fluxes. The data presented in this paper suggest that the heat loss from the lake-dominated tundra might also contribute to those high winter air temperatures. Zhang and others (1996) also reported that the maritime effect decrcases with distance from shore, and a colder, more continental winter climate prevails in the southerly regions of the North Slope. There is a significantly smaller areal fraction of lakes in this inland region (Sellmann and others, 1975); consequently, the colder climate may be due, in part, to a resultant lower areaweighted land-to-atmosphere heat loss.

\section{SUMMARY AND GONGLUSION}

The conductive heat fluxes through the snow cover on tundra, grounded ice and floating ice on the Alaskan North Slope have been estimated from field measurements made in mid-April 1997, and successfully simulated with a numerical model of the coupled snow/ice/water/soil system. The simulation helps to explain the differences in estimated fluxes through the snow on tundra, grounded ice and floating ice. Comparisons of the point (transect) estimates of the conductive heat flux with Antarctic sea-ice data, and the area-weighted heat-loss estimates with Arctic sea-ice data, indicate that energy flows from the lake-dominated Alaskan North Slope are on a par with those from the polar oceans. This large conductive heat flow through the snow may contribute to the spatial variability of the climate of the Alaskan North Slope.

The simulation of the heat fluxes for the entire winter of 1996-97 indicates that even greater heat transfer occurs earlier in the winter, although this will require proper validation with future field measurements. Further investigation of land-to-atmosphere heat transfer on the Alaskan 
North Slope and the interactions in the coupled air/snow/ ice/water/soil system would be warranted in view of the perceived sensitivity of the Arctic to climate change and the role of the Arctic in effecting climate change. To date, such investigations have tended to focus on the role of the Arctic Ocean and its sea-icc cover. This paper suggests the need for broader investigations of the role of the land surrounding the Arctic Ocean.

\section{ACKNOWLEDGEMENTS}

This work was supported primarily by NASA Polar Program grants NAGW-4966, NAG5-4170 and NAG5-4171 to Jeffries and Zhang. Jeffries' participation in the fieldwork at Barrow was partly supported also by the Japanese National Space Development Agency (NASDA) under the auspices of the ADEOS Cryosphere Validation program. He thanks F. Nishio and $\mathrm{H}$. Wakabayashi for making this possible, for being such cheerful and enthusiastic companions in the field and for providing the snow-density and temperature data. The Barrow Arctic Science Consortium (G. Sheehan, Director) provided logistical support. V. Kaupp (Chief Scientist, Alaska SAR Facility) expedited the delivery of the SAR data. Thorough and constructive reviews by two anonymous reviewers and by M. Sturm helped to improve the paper. Thanks are due to L. Hinzman for discussion of his investigations of activc-layer processes and heat fluxes, and to G. Maykut for responding to our late enquiry and request for comment on the fluxes. $\mathrm{M}$. Sturm loaned the snow-depth/temperature probes.

\section{REFERENCES}

Benson, C. S. 1982. Reassessment of winter precipitation on Alaskas Arctic Slope and measurements on the flux of wind blowen snow. Fairbanks, AK, University of Alaska. Geophysical Institute. (Report 288.)

Brewer, M. C. 1958. 'The thermal regime of an Arctic lake. Trans. Am. Geophys. Lnion, 39 2 ), 278-284.

Brown, J. 1969. Soil properties developed on the complex tundra relief of northern Alaska. Biul. Peryglac. 18, 153-167.

Brown, J. and P. I. Johnson. 1965. Pedo-ecological investigation, Barrow, Alaska. CRREL Tech. Rep. 159.

Chapman, W. L. and J. E. Walsh. 1993. Recent variations of sea ice and air temperature in high latitudes. Bull. Am. Meteorol. Sor., 74(1),33-47.

Coyne, P. I. and J. J. Kelley. 1974. Carbon dioxide partial pressures in Arctic surface water. Limnol. Oceanogr, 19(6),928-938.

Gosink, J. P. and T. E. Osterkamp. 1990. Models for pcrmafrost thickness variation in response to changes in paleoclimate. Collection Nordicana 54, Université Laval, Cenlre d'Études Nordiques, 191- 198.

Guymon, G. L. and T. V. Hromadka. 1977. Finite element model of transient heat conduction with isothermal phase change (two and three dimensional). CRREL Spec. Rep. 77-38.

Guymon, G. L., 'T.V. Hromadka and R. L. Berg. 1984. Two dimensional model of coupled heat and moisture transport in frost-heaving soils. $\underline{7}$. Energy Resour. Technol., 106(3), 336-343.

Hinzman, L. D., D. L. Kanc, R. E. Gieck and K. R. Everett. 199la. Hydrologic and thermal properties of the active layer in the Alaskan Arctic. Cold Reg. Sci. Technol, $19(2), 95-110$.

Hinzman, L. D., D. L. Kanc and R. E. Gieck. 1991b. Regional snow ablation in the Alaskan Arctic. $I n$ Prowse, T. D. and C. S. L. Ommanney, eds. Northern Hydrology: Selected Perspectives. Proceedings of the Northern Hydrology Symposium, 10-12 July 1990, Saskatoon. Saskatoon, Sask., Environment Canada. National Hydrology Rescarch Institute, 121-139. (NHRI Symposium 6.)

Jeffries, M. O., K. Morris, W. F. Weeks and H. Wakabayashi. 1994. Structural and stratigraphic features and ERS 1 synthetic aperture radar back- scatter characteristics of ice growing on shallow lakes in NW Alaska, winter 1991 1992. 7. Geophys. Res., 99 (C11), 22,459 22,473.

Lachenbruch, A. H. and B.V. Marshall. 1986. Changing climate: geothermal evidence from permafrost in the Alaskan Arctic. Science, 234(4777) 689-696.

Lachenbruch, A. H., M. C. Brewer, G.W. Greene and B.V. Marshall. 1962 Temperatures in pcrmafrost. Temperature - Its Measurement and Control in Science and Industry, 3(1), 791-803.

Lachenbruch, A. H., J. H. Sass, B.V. Marshall and T. H. Moses, Jr. 1982. Permafrost, heat flow, and the geothermal regime at Prudhoe Bay, Alaska. 7. Geophys. Res., 87(B1), 9301-9316. Ledley, T. S. 1988. A coupled energy balance climate-sea ice model: impact of sea ice and leads on climate. 7. Geophys. Res., $\mathbf{9 3}$ (1)12), 15,919-15,932.

Lytle, V. I. and S. F. Ackley. 1996. Heat flux through sea ice in the western Weddell Sea: convective and conductive transfer processes. 7 . Geophys. Res., 101 C4), 8853-8868.

Manabe, S. and R. J. Stoulfer. 1994. Multiple-century responsc of a coupled ocean atmosphere model to an increase of atmospheric carbon dioxide. 7. Climate, 7 $11,5-23$.

Massom, R. A., M. R. Drinkwater and C. Haas. 1997. Winter snow cover on sea ice in the Weddell Sea. 7. Geophys. Res, 102(Cl) 1101-1117.

Massom, R. A., V. I. Lytlc, A. P. Worby and I. Allison. 1998. Winter snow cover variability on East Antarctic sea ice. $\mathcal{I}$. Geophys. Res., 103 Cl1) $24,837-24,855$.

Maykut, G. A. 1978. Energy exchangc over young sea ice in the central Arctic. J. Geophys. Res., 83(C7), 3646-3658.

Maykut, G. A. 1982. Large-scale heat exchange and ice production in the central Arctic. 7. Geophys. Res., 87(C10), 7971-7984.

Moritz, R. E. and D. K. Pcrovich, eds. 1996. Surface heat budget of the Arctic Ocean science plan. Seattle, WA, University of Washington. (ARCSS/OAII Report 5.)

National Oceanic and $\Lambda$ tmospheric Administration (NOAA) 1997. Local climatological data, Barrow, AK, April 1997. Washington, DC, U.S. Iepartment of Commerce. National Oceanic and Atmospheric Administration.

Nelson, F. E., N. I. Shiklomanov, G. R. Mueller, K. M. Hinkel, D. A. Walker and J. G. Bockheim. 1997. Estimating active-layer thickness over a large region: Kuparuk River basin, Alaska, U.S.A. Arct. Alp. Res., 29(4),367-378.

O'Neill, K. 1983. Fixed mesh finite element solution for Cartesian 2-d phase change. 7. Energy Resour. Technol., 105(4), 436-441.

Osterkamp, T. E. 1987. Freezing and thawing of soils and permafrost containing unfrozen water or brinc. Water Resour. Res, 23 12), 2279-2285.

Osterkamp, T. E. and V. E. Romanovsky. 1997. Freezing of the active layer and permafrost on the North Slope of Alaska. Permafrost and Periglacial Processes, 811,23-44

Sollmann, P.V., J. Brown, R. I. Lewellen, H. McKim and C. Merry. 1975 The classification and geomorphic implications of thaw lakes on the Arctic Coastal Plain. CRREL Rer. Rep. 344.

Smith, S. D., R. D. Muench and C. H. Pease. 1990. Polynyas and leads: an overview of physical processes and environment. 7 . Geophys. Res., $95(\mathrm{C} 6)$, $9461-9479$.

Sturm, M. 1991. The role of thermal convection in heat and mass transport in the subarctic snow cover. CRREL Rep. 91-19.

Sturm, M. and J. Holmgren. 1994. Effects of microtopography on texture lemperature and heat flow in Arctic and sub-Arctic snow. Ann. Glaciol., 19,63-68.

Sturm, M., J. Holmgren, M. König and K. Morris. 1997. The thermal conductivity of seasonal snow. 7. Glaciol., 43(143), 26-41.

Sturm, M., K. Morris and R. Massom. 1998. The winter snow cover of the West $A$ tarctic pack icc: its spatial and temporal variability. In Jeffrics, M. O., ed. Antarctic sea ice: physical processes, interactions and variability Washington, DG, American Geophysical Union, 1-18. (Antarctic Research Series 74.)

Weeks, W. F., A. G. Fountain, M. L. Bryan and C. Elachi. 1978. Differences in radar return from ice-covered North Slope lakes. 7. Geophys. Res, 83( C8), 40694073.

Weller, G. and B. Holmgren. 1974. The microclimates of the Arctic tundra. 7. Appl. Meleorol., 13 8 ), 854-862.

Zhang, T., T. E. Osterkamp and K. Stamnes. 1996. Some characteristics of the climate in northern Alaska, U.S.A. Arct. Alp. Res., 28(4), 509-518.

Zhang, T., T. E. Osterkamp and K. Stamnes. 1997. Effects of climate on the active layer and permafrost on the North Slope of Alaska, USA. Permafrost and Periglacial Processes, $8(1), 45-67$. 